\title{
Recovering the Curse of Eve: John Donne's Churching Sermons
}

\section{JEFFREY JOHNSON}

Résumé: L'office liturgique de relevailles ("Churching of Women after Childbirth"), tout en ayant son origine dans les lois de purification détaillées au Lévitique 12, s'était néanmoins transformé, à l'époque où John Donne servait de prêtre, en occasion surtout sociale. Les deux sermons de relevailles de Donne qui ont été préservés répondent à cette tendance en situant la pratique dans un contexte de repentir collectif. En particulier, Donne aligne les relevailles sur le sacrement de baptême; dans cette optique, la purification qu'il préscrit, encore que liée au nettoyage corporel, est élargie théologiquement pour illustrer le besoin de toute l'humanité d'être lavée de sa déchéance.

Tn accordance with his clerical duties as a priest of the Church of England, John Donne performed churching services as specified in the Book of Common Prayer. The churching of women, a service of thanksgiving for the safe delivery of the mother from the perils of childbirth, was a regular part of the liturgical life of the Church. Although the service in the Prayer Book is characterized by its simplicity, an array of customs and practices had become attached to churching that overemphasized its social function and had little to do with the biblical and theological underpinnings for the service. It is within this historical context, and the precise cultural tensions arising from it, that Donne's extant churching sermons must be placed in order to read Donne properly both as a priest and as a religious thinker.

There is a variety of historical evidence from the late sixteenth and early seventeenth centuries indicating the displeasure of some individuals with the 
practice of the churching of women, such as the objections raised by dissenting Puritans in An Admonition to the Parliament (1572):

Churching of women after childbirthe, smelleth of Jewishe purification: theyr other rytes and customes in their lying in, \& comming to church, is foolishe and superstitious, as it is used. She must lie in with a white sheete uppon her bed, and come covered with a vayle, as ashamed of some folly. ... They pray that all men may be saved, \& that they may be delivered from thundering \& tempest, when no danger is nighe. ${ }^{1}$

As this passage indicates, the complaints during this period focus generally on matters of custom that fall outside what is specified in the Prayer Book. The wearing of a white veil, in particular, was often insisted on by more conservative members of the clergy, and there was even a legal judgment in the reign of James I upholding this stricture. ${ }^{2}$ Additional complaints centered on the unscriptural nature of the ceremony and the clergy's demand for payment, ${ }^{3}$ and the judicial records indicate that women were prosecuted for the kind of behavior exemplified by one who, according to a brief notice, came to be churched "undecently and unwomanly without any woman with her." 4 By and large, however, records from the period reveal that the overwhelming majority of women complied with and even affirmed the practice. For example, Jeremy Boulton's study of the Boroughside district of St. Saviour's, Southwark (located on the south bank of the Thames between London Bridge and Lambeth Marsh), reveals that upwards of $93 \%$ of those eligible were churched in a timely manner during the years 1619-25. ${ }^{5}$ In addition, the historical work by F. G. Emmison and William Coster demonstrates not only that "refusing to go to be churched was not a common offence," but also that "the majority of women continued to acquiesce in, many actively to support, the ceremony as a social necessity."6

Taken together, what the scattered complaints and the widespread complicity of the women seem to signal is that by the time of John Donne's clerical career, the churching of women had become primarily social in its function and practice. Because of the isolation women endured during the months prior to and after delivering their children, the churching service had taken on the secular taint of something akin to a coming-out celebration, for, as Coster argues, "the ceremony of churching was the only means by which, after childbirth, a woman could return to the community of the Church, and indeed to society in general." In spite of the fact that canon law actually specified that such isolation was not required, popular practice and belief dictated otherwise. Within this historical context, Donne's two extant churching sermons, the one for Lady Doncaster (Lucy Percy) and the other 
for the Countess of Bridgewater (Frances Egerton), serve as orthodox correctives for recovering the larger theological significance of the churching service, which had become overshadowed by the social importance attached to it. Insofar as these sermons are both extended homilies on the doctrine of repentance, Donne seeks to dilate his auditors' understanding of churching beyond the strict biblical and liturgical contexts informed by Eve's fall and her resultant curse of travail in childbirth. Instead, Donne reads the churching of these aristocratic women in terms of the fallen condition of all humanity and thereby fulfills his own sense of calling by preaching the gospel of repentance.

There is little doubt that the service for the churching of women, a practice carried over from the medieval church, was derived from the Old Testament laws of purification for women after childbirth. Leviticus 12 specifies that a woman was considered unclean for seven days following the birth of a male child (fourteen for a female) and continued in "the days of her purifying," prohibited from touching anything holy and from entering the sanctuary, for another thirty-three days (sixty-six if the child was female). After completing this period of purification, the new mother then brought to the priest a year-old lamb for a burnt offering and a pigeon or turtledove for a sin offering, although if she could not afford a lamb, she could bring two pigeons or two turtledoves (one for each offering).

The Church of England Prayer Book service does not directly characterize the service as one of purification, labeling it instead "The Thanksgiving of Women after Childbirth." 8 By custom, one undoubtedly influenced by the number of days of purification specified in Leviticus, the churching occurred roughly one month after the woman had given birth. ${ }^{9}$ To begin the service, the woman was to kneel "in some convenient place nigh unto the place where the table standeth," although by Donne's time there was a pew designated for this purpose, ${ }^{10}$ and the priest then expressed to the woman his gratitude that God "hath preserved you in the great danger of childbirth."11 This pronouncement was followed by a reading of Psalm 121, a reciting of the Lord's Prayer, and finally a prayer by the priest, in which he again thanked God, who has "delivered this woman thy servant from the great pain and peril of childbirth." 12 The comments on the danger and pain of childbirth framing the churching service not only speak to the historical reality of the high mortality rate for both children and mothers during this period, but also allude to the curse Eve received because of the part she played in the Fall: "I will greatly multiply your pain in childbearing; in pain you shall bring 
forth children" (Gen. 3:16). Following the service, the woman was then instructed, again with an obvious parallel to the Old Testament laws, to provide an offering, which in this case was a monetary one of anywhere from $4 \mathrm{~d}$. to $11 \mathrm{~d}$., though if the child had died it was typically $1 \mathrm{~d}$. or $2 \mathrm{~d} .{ }^{13}$

In his brief defense of the churching service from his Ecclesiastical Polity, Richard Hooker asserts at the outset, "The fruit of mariage is birth, and the companion of birth travaile, the griefe whereof being so extreeme, and the daunger alwaies so great" that, he continues, "wee can never sufficientlie praise [the Lord] nor give him thankes for halfe those benefites for which this sacrifice were most due." 14 Further, Hooker specifically addresses the one-month period between the birth of the child and the churching service and notes, in response to popular belief, 15 not only that canon law prescribes no such period, but, more importantly, that during this time of lying-in, the woman "is not barred from thence in such sort as they interpret it, nor in respect of anie unholines forbidden entrance into the Church" (2: 408 [V.lxxiv.2]). Finally, Hooker defends the offering accompanying the churching of women by explaining that it is "a part of the ministers right" and that, "as the life of the clergie is spent in the service of God, so it is susteined with his revenue" (2: 409 [V.lxxiv.4]).

While Donne certainly draws on these biblical and liturgical contexts, which emphasize purification and the curse of Eve, he locates these concerns within the broader theological scope of the spiritual cleansing that comes through repentance, preaching and the Sacraments. The sermon for the churching of the Countess of Bridgewater (Frances Egerton), which Simpson and Potter speculate was preached in 1621 or $1623,{ }^{16}$ is actually two sermons explicating Micah 2:10 ("Arise and depart, for this is not your rest"). Dennis Flynn has recently demonstrated that Donne had known Frances Egerton from her early childhood, while he served in the household of Henry Stanley, ${ }^{17}$ yet in spite of this long-time association, the first of the two sermons is a lengthy and rather impersonal meditation from biblical history on the sinful, fallen condition of the Israelites. In their introduction to the sermon, Simpson and Potter express their belief that Donne divided what was initially one sermon into two only when he had written it out sometime after preaching it and, further, that "in the original sermon it is probable that the long disquisition on God's judgments on the Jews which occupies most of the first of these two sermons was compressed into a few paragraphs, as it would be very unsuitable for the churching of any lady" (5: 14). While their conjecture that Donne lengthened the original text may be correct, it is 
unnecessary to dismiss the material from the first of the two sermons simply on the grounds of its inappropriateness. Just such an extended recounting of human sinfulness speaks directly to Donne's desire to raise this churching service above the secular context of the time in order to attend to the vocational responsibility he expresses throughout the Sermons of instilling genuine contrition in his auditors.

Donne's initial assertion that "the Gospell is repentance, and remission of sinnes" (5: 260) responds, of course, to Luke 24:47 and also echoes Calvin's statement that "the sum of the gospel is held to consist in repentance and forgiveness of sins." 18 Throughout the Sermons, Donne assumes the sinful nature of humankind, but while he acknowledges that all are born into original sin, he reminds his auditors of the continual need both to repent and to avoid repeating habitual sins:

This onely is true Repentance, Plangere \& plangenda non committere, To bewayle our sins, and forbeare the sins we have bewayled. Neither alone will serve; which deludes many. Many thinke they doe enough if they repent, and yet proceed in their sin; and many thinke they doe enough, if they forbeare their sin now, though they never repent that which is past; both are illusory, both deceitfull distempers. $(9: 325)^{19}$

This awareness of the fallen human condition and the biblically informed necessity of repentance speaks directly to Donne's own acknowledgement of his clerical responsibility. On 13 October 1622, Donne preached at St. Paul's the last of his three sermons on John 1:8 ("He was not the light, but came to bear witness to the light"), and in it he asserts in no uncertain terms for his auditory the direct commands of God to his ministers: "Our Commission is to conform you to him, our Instructions are to doe that, that way, By preaching the Baptisme of Repentance, for the remission of sinnes" (4: 229). Donne, however, goes further in this sermon. Beyond his obligation to preach, as well as his auditors' to repent, Donne elaborates on the notion of witness from his scripture text. In particular, he explains that preaching the promises of the gospel and administering the Sacraments that seal those promises declare together the truth of Christ in the world, and in response to the Word and the Sacraments, he enjoins his congregation, "witnesse to others, by thy exemplar life, and holy conversation" (4:234). Earlier in the sermon, he summarizes as follows: "This then is the chain; we preach, you repent; then we give you the Seals, the Sacraments, and you plead them, that is, declare them in a holy life; for, till that (Sanctification) come, Preaching, and Repentance, and Seals, are ineffectuall" (4:230). 
Donne demonstrates his intention to initiate this chain of sanctification when he delineates the three-point explication of his scripture text: "The first was a Commination, a departing without any Rest, propos'd to the Jewes; The second was a Commonition, a departing into a way towards Rest, proposed to repentant sinners; And this third is a Consolation, a departing into Rest it selfe, propos'd to us, that beleeve a Resurrection" (5: 209). This division, tracing as it does the salvific movement from fallenness to confession to consolation, articulates the doctrine of repentance as the remedy for human sin in general that Donne applies personally to Frances Egerton in the opening paragraph of the second sermon, when he writes that the words "arise" and "depart"

admit a just accommodation to this present occasion, God having rais'd his honorable servant, and hand-maid here present, to a sense of the Curse, that lyes upon women, for the transgression of the first woman, which is painfull, and dangerous Child-birth; and given her also, a sense of the last glorious resurrection, in having rais'd her, from that Bed of weaknesse, to the ability of coming into his presence, here in his house. (5: 198)

The obvious allusion here to Genesis 3:16 links the churching of Lady Bridgewater, through the reference to the resurrection in the community of the Church, not only to Eve and the sufferings of childbirth, but also to the genderless curse of original sin. Donne perceives Frances Egerton as a microcosm, not simply of the female condition, but more broadly - indeed principally - of the human condition, as he spells out later in this second part:

A Christian Mother does not conceive a Christian; onely the Christian Church conceives Christian Children... . The Parents may be up, and ready, but their issue abed, and in their bloud, till Baptisme have wash'd them, and till the spirit of Regeneration have rais'd them, from that bed, which the sins of their first Parents have laid them in, and their own continuing sins continued them in. This rising is first, from Originall sin, by baptism, and then from actuall $\sin$, best, by withdrawing from the occasions of tentation to future sins, after repentance of former. $(5: 205)$

Theologically, Donne links the churching of women with baptism in the larger context of the doctrine of repentance, which fulfills the regenerative needs of all humanity in the publicly administered Ordinances of the Church, for the Church alone "conceives Christian Children."

These same ideas on the doctrine of repentance, along with the association of penitent tears and baptism, are further elaborated in the sermon for the churching of Lady Doncaster, which Simpson and Potter date with certainty as being preached in December, $1618 .{ }^{20}$ The delivery and reception 
of this sermon must have taken place in an atmosphere of personal sadness. For James Hay and Lucy Percy (Viscount and Lady Doncaster), this sadness would have resulted from the fact that their son, who was baptized Charles, lived only a few days and had been buried in the churchyard of St. Clement Danes on 3 December. Donne's own sadness would have stemmed not only from sharing in the grief of his friends and patrons, but also, one would assume, from recalling his own loss sixteen months prior of his wife Ann, who was buried in the same churchyard.

The biblical text for Lady Doncaster's churching sermon is Canticles 5:3 ("I have washed my feet, how shall I defile them?"), and in its explication Donne concentrates on the need for washing - not a physical cleansing, but a spiritual purification such as is required of all, initially because of original sin and thereafter because of actual sins. In fact, the churching sermon for Lady Doncaster, with the motif of water and washing developed from its scripture text, touches the association Donne makes throughout the Sermons between repentance and tears. To the extent that repentance is an act of purification for habitual sins, tears of contrition are for Donne the bodily emblem for that spiritual cleansing. Such tears are, he writes, "the Ambassadours of sorrow" and "the bloud of a wounded soule" (5: 54), and because they testify to the divine promise that the sorrow necessitating them will be removed in heaven, Donne exclaims, "You must weepe these teares, teares of contrition, teares of mortification, before God will wipe all teares from your eyes" (4: 45).

Tears of contrition are for Donne, most importantly, a theological complement to, and a type for, the waters of baptism. "Christ and his Apostles," he writes, "had carried two Waters about his Church: The water of Baptisme [and] the water of contrite teares, and repentance" (9:329), and, as he specifies in another sermon, "he that comes washed with the water of Baptisme in his infancy, and he that comes washed with the teares of Repentance in his age, may receive health and cleannesse" $(5: 85)$. Therefore, repentance is for Donne "the second Baptism" (10:186), or as he states elsewhere, the resurrection from sin "is begun, and well advanced in Baptismate lachrymarum, In the baptisme of true and repentant teares" (7:213). Noting in yet another sermon that God began the Christian Church with the sacramental water of baptism, Donne exhorts his auditors, "Pursue his Example; begin thy Regeneration with teares" (9:291), and in one of his christening sermons, he declares that salvation is made sure by water and by blood: 
If thy heart, and bowels have not yet melted in compassion of his passion for thy soule, if thine eyes have not yet melted, in teares of repentance and contrition, he is not yet come by water into thee; If thou have suffered nothing for sinne, nor found in thy selfe, no resistance of Concupiscences, he that comes not to set peace, but to kindle this war, is not yet come into thee, by bloud. (5: 137)

In his churching sermon for Lucy Percy, the washing that Donne specifies as "absolutely, generally necessary" is that of baptism, and the washing that is "occasionally necessary" from habitual sins occurs in "the bloud of our Saviour in the Sacrament" (5: 176). Both are requisite for salvation, and both, as communal acts of repentance, must be received in the Church, for Donne writes of these two Sacraments, "fons in Ecclesia, the whole spring, and river is in the Church, there is no baptisme, no bloud of Christ, but in the Church" (5: 176). Donne notes further, however, that between baptism and the Lord's Supper there is another washing, "the water of Contrite, and repentant teares, in opening our selves to God, and shutting up of our selves against future tentations" $(5: 176)$. While Donne admits that this third type of washing can take place in an act of private repentance, he argues strongly for the efficacy of public repentance: "of this water, there is Pelvis in Ecclesia, the Bason is in the Church; for our best repentance (though this repentance be at home in our owne hearts) doth yet receive a Seale, from the absolution of Gods Ministers in the Church" (5: 176). In emphasizing communal repentance, Donne comes very near in this passage to naming repentance as a sacrament by identifying it as a seal received from "Gods Ministers." 21 As in the sermon for the Countess of Bridgewater, this homily for Lady Doncaster is not a simplistic pronouncement of purification for and delivery from the pain and danger of childbirth, nor is it a fawning celebration for the return to society of this woman of society. Instead, Donne calls all those in attendance to a communal participation in the body of Christ. Noting the context of Christ washing the feet of the Apostles at the Last Supper, Donne states in the sermon for Lucy Percy:

If we come not to this washing of our feet, this preparatory washing by teares of repentance, we can have no part in him, that is, in the participation of his body, and his bloud; . . . let us often call our selves to account, implore the councell often, often accept the absolution of Gods Minister, and often settle our soules, in a true peace, by a worthy receiving of the seale thereof, in the Sacrament. (5: 179)

In his article examining the churching of women during the English Renaissance, William Coster states, "it would be easy to argue that the 
churching of women was not only religiously offensive, but personally insulting to these women," 22 especially in the light of the forced isolation (both from the lying in and during the service itself), the association of the pains of childbirth with the curse of Eve, and the implication from the Old Testament purification laws of women's bodies as unclean. Certainly, from a late twentieth-century perspective this liturgical practice seems offensive and insulting. Nevertheless, in reading Donne's Sermons, as Jeanne Shami rightly and succinctly argues, "context is all." 23 While Donne's individual sermons are too often seen as not "issuing from any specific context generic, historical, theological, political, or cultural," Shami asserts that such fragmentary and uncontextualized readings are, more often than not, the result of critics seeking "confirmation of Donne's grasping, egotistical nature."24 The churching sermons for Lady Doncaster and the Countess of Bridgewater, when properly contextualized, reveal Donne's theological and ministerial integrity in the midst of a cultural view of churching as merely ceremonial. The purification Donne prescribes in the sermons for these two aristocratic women, while associated with the bodily cleansing outlined in Leviticus, derives fundamentally from his own sense of calling to preach the gospel that is repentance. In these sermons, he enlarges the need for purification to include all of fallen humanity; the churchings of Frances Egerton and of Lucy Percy were for him particular occasions that touched the more universal condition of human sinfulness. Because of original sin, as well as the inevitability of actual sins, birth brings with it death, and as Donne makes clear in these churching sermons, the only way to life, the only way to seal one's repentance, is through a communal participation in the Word and the Sacraments.

Northern Illinois University

\section{Notes}

1. W. H. Frere and C. E. Douglas, eds., Puritan Manifestoes: A Study of the Origin of the Puritan Revolt (London: S.P.C.K., 1954), pp. 28-29.

2. See Jeremy Boulton, Neighbourhood and Society: A London Suburb in the Seventeenth Century (Cambridge: Cambridge University Press, 1987), p. 276, and Keith Thomas, Religion and the Decline of Magic: Studies in Popular Beliefs in Sixteenth and Seventeenth Century England (London: Weidenfeld and Nicolson, 1971), pp. 59-60.

3. Cf. Patricia Crawford, Women and Religion in England, 1500-1720 (London and New York: Routledge, 1993), p. 55, and F. G. Emmison, Elizabethan Life: Morals and the Church Courts, Elizabethan Life, vol. 2 (Colchester, England: Benham, 1973), pp. 159-61. 
4. Cited in Emmison, p. 160.

5. Boulton, pp. 277-78.

6. Emmison, p. 159; William Coster, "Purity, Profanity, and Puritanism: The Churching of Women, 1500-1700," in Women in the Church, Studies in Church History, vol. 27, ed. W. J. Sheils and Diana Wood (Oxford: Blackwell, 1990), p. 386.

7. Coster, p. 377.

8. The Book of Common Prayer, 1559: The Elizabethan Prayer Book, ed. John E. Booty (Charlottesville: University Press of Virginia for the Folger Shakespeare Library, 1976), p. 314.

9. See Boulton, p. 278 , and Coster, pp. 380, 385-86.

10. Coster, pp. 382-83.

11. The Book of Common Prayer, 1559, p. 314.

12. Ibid., p. 315.

13. See Boulton, p. 277, and Christopher Hill, Economic Problems of the Church: From Archbishop Whitgift to the Long Parliament (Oxford: Clarendon, 1956), p. 168.

14. Richard Hooker, The Folger Library Edition of the Works of Richard Hooker, gen. ed. W. Speed Hill, 5 vols. (Cambridge: Belknap Press, 1977), 2: 406, 407 (V.lxxiv.1). Subsequent references will be incorporated parenthetically in the text.

15. Boulton notes that "associated with the element of purification ran a strong popular belief that women who died in childbed before being churched could not be given Christian burial" (p. 276). Further, Thomas recounts that "even at the end of the seventeenth century it was reported from parts of Wales that 'the ordinary women are hardly brought to look upon churching otherwise than as a charm to prevent witchcraft, and think that grass will hardly ever grow where they tread before they are churched"" (p. 39).

16. John Donne, Sermons, ed. G. R. Potter and Evelyn M. Simpson, 10 vols. (Berkeley: University of California Press, 1953-62), 5: 184-97 (Sermon No. 9). (This edition is used for citations, with volume and page numbers supplied parenthetically in the text.) In their introduction to this sermon, Simpson and Potter conjecture that although the Countess of Bridgewater had fifteen children, this sermon very likely "was preached after the birth of an heir, for most of the children were daughters" (5: 14). They then note a letter from Chamberlain, dated 2 June 1621 , recording the birth of a son, who, unfortunately, died early in 1623; however, Chamberlain also records that the Countess was pregnant at this time and that two months later, in June, she gave birth to another son, John, "who survived his father and became the second Earl of Bridgewater" (ibid.).

17. Dennis Flynn, John Donne and the Ancient Catholic Nobility (Bloomington: Indiana University Press, 1995), pp. 172, 177.

18. Jean Calvin, Institutes of the Christian Religion, ed. John T. McNeill, trans. Ford Lewis Battles et al., Library of Christian Classics, vols. 20-21, 2 vols. (Philadelphia: Westminster Press, [1960]), 1: 592 (III.iii.1).

19. Donne's language here is similar to that of Hooker, who explains that repentance is "a vertue, that hateth, bewayleth, and sheweth a purpose to amend sinne" (3: 12 [VI.iii.5]). 
20. In their introduction to this sermon, Simpson and Potter note that "the register of baptisms at St. Clement Danes Church, London, records for November 27, 1618, 'Charles Hay, Sonne to the Lord Hay, Viscount Doncaster, baptised in Essex House"' (5: 12) and comment further that this was the only child Lady Doncaster, who was then nineteen, would bear.

21. See Calvin, who defines a sacrament as "a seal by which God's covenant, or promise, is sealed" (2: 1450 [IV.xix.2]). The point here is that penitence is a Roman Catholic sacrament, as affirmed by the Council of Trent, and thus Donne seems to blur the doctrinal distinctions between Roman Catholicism and orthodox Protestantism.

22. Coster, p. 386.

23. Jeanne Shami, "The Absolutist Politics of Quotation," in John Donne's Religious Imagination: Essays in Honor of John T. Shawcross, ed. Raymond-Jean Frontain and Frances M. Malpezzi (Conway: University of Central Arkansas Press, 1995), p. 383.

24. Ibid., pp. 383, 389. 